\title{
The Internal Examination of Ideology and Politics Education in Colleges and Universities under the Perspective of Social Subject Research Method
}

\author{
Duanxian Wang* \\ College of Civil Engineering, Xi'an University of Technology, Xi'an, Shanxi, 710048, China
}

\section{ARTICLE INFO}

Article history

Received: 14 September 2021

Revised: 25 September 2021

Accepted: 15 October 2021

Published Online: 30 October 2021

Keywords:

University ideology and political education

Social subject research method

Subjectivity

Marxism

Inner-examination

\section{Introduction}

"Subject" is the important category in ideology and politics education. Just like social and historical process is realized by social historical subject, the ideology and politics education is realized by the subject in thought and politics education. Examining the inner activity of ideology and politics education must look into the subject effect and subjects themselves in the ideology and politics education activity. The basic foundation of "real people" and "people as subject" must be held. Basing on this, insist to give inner look to thought and politics education in universities from the point of view of Marxism social subject method has theoretical and realistic importance.

\begin{abstract}
Human is the subject of social and historical development process. The essence of human is the sum of social relations, and the masses are the creators of history. This is the basic content of social subject research methods, and also an important principle that must be followed by the subject category in ideology and politics education in colleges and universities. From the perspective of social subject research methods, the internal examination of the thought and politics education activities in colleges and universities should include three basic dimensions: adhering to examine the ideological and political moral construction activities via communicative practice, adhering to the principle of "all members, whole process and all dimensions (three-all principle)" to examine the "macro ideological and political" education concept, and adhering to the examination of the innovation of the ideology and politics education method system in higher education for the promotion of students' subjectivity.
\end{abstract}

\section{People is the Subject of Historical Develop- ment: Adhering to Examine the Ideological and Political Moral Construction Activities via Communicative Practice}

People is the subject of historical development, which means "people" must be considered as the initial concept in any of the social and historical researches, which of course include the ideology and politics education. In the Marxist research method of social subject, the people as social historical subject is not metaphysical and abstract, but "real people" which are in the certain communicative relationship. As the basic and general category built by Marx and Engels, "Communication" represents for the unity of activity of the interaction and development of real person and community mentally and physically and the interactive relationship based on those activities in certain historical conditions ${ }^{[1]}$. Correspondingly, thought and politics education in universities is a constructive activity of ideological and political morality, which itself is the unity of relationship of educator and the educated in certain

*Corresponding Author:

Duanxian Wang,

College of Civil Engineering, Xi'an University of Technology, Xi'an, Shanxi, 710048, China;

Email:412216700@qq.com 
historical conditions, which is though mainly mental. Based on that, the universities must examine the ideological and political moral construction via communicative activity, instead of peaching.

Examine the ideological and political moral construction via communicative activity requires the universities regard the educated as independent subject, constructing interactive relationship and process in education, unifying dominance and subjectivity. This requires that the educator in universities apply the principle of communicative activity through all the process of the ideological and political construction, which includes the stimulation of ideological and moral development needs and the acquisition and comparison of ideological and moral information, the integration and renewal of ideological and moral concept system, and finally the performance and reflection of ideological and moral behavior, thus build a positive interactive relationship between teachers and students. Fundamentally, it is essential to abandon the use of objectoriented thinking to explore the whole process of ideology and politics education, instead, examining the whole process of ideology and politics education activities with the thinking of communicative practice, so as to keep the elements of the process of ideology and politics education and their relationships effective, and then guide the effective operation of the process of ideology and politics education ${ }^{[2]}$. Secondly, in the moral construction activities of thought and politics education, universities must take the task of stimulating the self-moral construction ability of educational objects as the core practice orientation. That"s because the essence of thought and politics education is the activity of constructing ideological and political moral of the educated in the instruction of the educator's sense of value, and evoke the realistic and possible subjectivity of students in the process ${ }^{[3]}$. In this sense, the ideology and politics education in universities promotes the realization of the subjectivity of the students.

\section{The Essence of Human Beings is the Sum- mation of Social Relations: Adhere to the "Three-all Principle" to Examine the "Macro Ideological and Political" Education Concept}

Under the method of social subject, human is not only an abstract person in concept, nor an abstract person as a single person, but the sum of social relations that are interrelated and interact with each other. In terms of each educational object in the thought and politics education activities in colleges and universities, it is not only an abstract person representing individuals, but the sum of its social relations. In the sum of this social relationship, at least the relationship between teachers, parents, friends, classmates and other personnel of the education object is involved, that is, the multiple relationships such as family, school and society must be included in the consideration of relationship in thought and politics education in colleges and universities. In this sense, the ideology and politics education in colleges and universities should adhere to the education concept of "macro ideology and politics education", holding a general view and general method to strengthen and improve the ideology and politics education in colleges and universities from the overall situation and fundamental condition, emphasizing wide range of educating participation, the extensive use of space and time, the pertinence and openness of the content system as well as the complementarity of virtual reality in the use of platforms ${ }^{[4]}$. In short, participate, concern and work for all the members, in the whole process and from all the dimensions. From above, it's necessary for the universities to examine the "macro ideological and political "education concept through the "threeall principle" of all members, all the process and all the dimensions.

The "three-all principle" is not merely theoretical repetition. Although "three-all principle" and "macro ideological and political" education concept emphasize multiple subjects, various situations and unified education, highlighting the epitaxy of traditional class equally, ${ }^{[5]}$ "three-all principle" actually provides a instruction for the realization of "macro ideological and political " education concept. Controversially, in order to solve the problem of weak coupling, the "three-all principle" in colleges and universities in the new era must concentrate on the "macro ideology and politics education", planting the line of thought and politics education in the whole process of education and teaching, constructing the working pattern of "macro ideology and politics education" and highlighting the traction of education ${ }^{[6]}$.

Insist examining the "macro ideological and political" education concept with "three-all principle" represents in three dimensions of subject, time and space. For the subject, the universities have to effect as the instructor of ideological and political course, the core participator as tutor and the teacher in charge, the server of administrator in teaching, and cooperate with social education, family education and self-education to construct the sound environment of "macro ideological and political" education concept. For time dimension, the universities should insist thought and politics education through all the process of student's growth and progress form admission to graduation, scientifically distribute the weight of family, school and society in the growth of students, influencing the student with the right sense of value in 
explicit and explicit education. For the space dimension, the universities should make good use various situations, such as research, campus, consultation, activities and administration, to conduct the ideology and politics education.

\section{People Create the History: Emphasizing the Subjectivity of Students in the Examina- tion of the Innovation of Ideology and Politics Education Method in Higher Education}

"People create the history" is a basic principle of historical materialism, the recognition of decisive power of people in the development of society and history. In the ideology and politics education in colleges and universities, on the one hand, the construction and development of ideology and politics education relies on the layout and intensive cultivation of ideological and political educators. On the other hand, it relies on the selfabsorption of the thought and politics education content and the self-construction of the ideological and political moral value of the educated students. The former must ultimately rely on the latter in order to truly realize the goal of thought and politics education. In this process, in order to continuously improve the pertinence and timeliness of thought and politics education, colleges and universities must solve, promote and innovate according to the issues, the time and the situation, in order to stimulate students' subjectivity in thought and politics education activities, and constantly innovate the method system of thought and politics education. Only in this way can students strengthen their self-absorption ability of thought and politics education content and selfconstruction of ideological and political moral value. At the same time, the students' ideological and moral development level is also the measurement of thought and politics education method system innovation. Based on the analysis above, we should examine the innovation of ideology and politics education method system based on the subjectivity of students.

Chinese President Xi Jinping pointed out in his speech at the "Teacher's Seminar on Ideological and Political Theory Courses in Schools' that "The education of ideological and political courses cannot be separated from the teacher's guidance. In the meantime, we should adhere to the student-centered principle, enhance the research on the cognitive development and acceptance characteristics, and make it effective of the role of students' subjectivity ${ }^{[7]}$. And examine the ideology and politics education method system innovation, via students' subjectivity requires to strengthen the research of students' cognitive law and acceptance characteristics, and take it as the theoretical basis for the thought and politics education method system innovation. In the meantime, it is essential to establish the subjective evaluation system of students in the thought and politics education in colleges and universities scientifically, so as to provide a correct direction for the innovation of the method system in thought and politics education. In addition, colleges and universities should adhere to the practical education as an important model for the innovation of the system of thought and politics education methods, so as to realize the return of practice, value rationality and social reality in thought and politics education activities at the cognitive level ${ }^{[8]}$. This is because only when the thought and politics education is integrated into the "knowledge and will" of individuals and transformed into the spirit of practicing which guides individual action, can it truly reveal the vitality of the students in the process of ideology and politics education.

\section{References}

[1] Fan, Baozhou (2005). On Marx's theory of communication and its contemporary significance. Beijing: Social Science Literature Press, Page 22.

[2] Liu Wei (2008). Research on Ideology and politics education of Communication Practice. Central China Normal University.

[3] Chu Fengying (2015). Subjectivity Analysis of Ideology and politics education Object. School Party Construction and Ideological Education. Page: 19-23.

[4] Chu Defeng (2012). The characteristics and ideas of the "big ideological and political" education mode in colleges and universities. China's higher education, Page: 34-36.

[5] Cheng Tao (2019). Exploration and Practice of Constructing the Great Ideological and Political Pattern of Higher Vocational Colleges from the Perspective of "Three All-round Education". Educational Modernization. Page: $259-260+263$.

[6] Ding Dan (2020). Exploration of "Three All-round Education" in Colleges and Universities in the New Era : Mechanism, Problems and Directions. Ideological Education Research. Page: 119-123.

[7] Xi Jinping (2020). On the Party's propaganda and ideological work. Beijing: Central Literature Press. Page: 385-386.

[8] Tian Chuanxin (2013). Practice Education Mode and Value of Ideology and politics education in Colleges and Universities from the Perspective of Ideology and politics education. Journal of Zhejiang Shuren University (Humanities and Social Sciences Edition ). Page: 106-110. 